\title{
HEALTHY LIFE BEHAVIOR IN PREGNANT WOMEN WITH RISK OF PREECLAMPSIA IN THE PHC OF CIPARAY BANDUNG DISTRICT
}

\author{
Hanifa Iqomatulhaq ${ }^{1}$, Ermiati ${ }^{1}$, Tetti Solehati ${ }^{1}$ \\ Faculty of Nursing, Universitas Padjadjaran \\ Correspondance: hanifaiqomatulhaq77@gmail.com
}

\begin{abstract}
Poor healthy living behaviors would increase the risk of pregnant women getting preeclampsia. Healthy living behavior prevents the occurrence of preeclampsia. This study aimed to analyze healthy behavior in pregnant women with a risk of preeclampsia in the work area of Ciparay Health Center, Bandung Regency. The research method used was quantitative descriptive. The population in this study were 36 pregnant women with a risk of preeclampsia who were selected using the total sampling technique. This study used a questionnaire instrument modified from HPLP II with a valid test of 0.494-0.864 and the value of Cronbach's alpha 0.950. This instrument had an average range of scores from 1-4 with a mean value of 3.11. Healthy living behavior was considered high if the average score was $\geq 3.11$ and was considered low if the score was $<3.11$. The study was conducted on 7-16 October 2018. The results of this study indicated that the healthy behavior of pregnant women with a risk of preeclampsia in the Ciparay Community Health Center work area was in the high category of 20 respondents $(55.6 \%)$. Also obtained the lowest dimensions were interpersonal relationships, physical activity, and nutrition. The conclusion was pregnant women with the risk of preeclampsia have a poor healthy living behavior, especially in the dimensions of physical activity and nutrition. Therefore, a strategy or program is needed to improve the healthy behavior of pregnant women at the risk of preeclampsia.
\end{abstract}

Keywords: healthy living behavior, pregnant women, the risk of preeclampsia.

\section{INTRODUCTION}

Maternal Mortality Rate (MMR) is one of the indicators for the success of maternal health programs. In 2015 the MMR of Indonesia was recorded at 305 deaths per 100,000 live births (Indonesian Ministry of Health, 2015). In West Java Province based on the Routine Data of the West Java Provincial Health Office in 2016, the number of maternal deaths was 790 people and there was a decrease in the number of maternal deaths to 394 in 2017. In Bandung Regency in 2016, there were 46 cases of maternal deaths with various causes (District Health Office Bandung, 2016).

According to the West Java Health Office (2017) there are five biggest causes of maternal death, namely pregnancy hypertension (PH), bleeding, circulatory system disorders (heart, stroke, etc.), infections, and others. Where pregnancy hypertension $(\mathrm{PH})$ is the number one contributor to the maternal 
mortality rate in West Java. In Bandung Regency, the number of maternal deaths in 2017 was 26 people, with causes due to bleeding as many as 7 people $(26.92 \%)$, and PH including preeclampsia is as many as 7 people (26.92\%). Based on these data the causes of maternal mortality in Bandung Regency are still dominated by bleeding and preeclampsia.

Preeclampsia is a health problem during pregnancy, which is characterized by an increase in blood pressure and proteinuria which occurs due to a disruption of the mother's cardiovascular and kidney systems. Preeclampsia causes various complications to the mother such as eclampsia, placental abruption, hemolysis, cerebral hemorrhage, and maternal death (Wiknjosastro, Saifuddin, \& Rachimhadhi, 1999). Complications in the fetus are intrauterine growth retardation, low birth weight, acute hypoxia, prematurity and intauterous death (IUFD) (Saifuddin, 2006).

Risk factors for preeclampsia are a pregnancy with a systolic blood pressure more than $140 \mathrm{mmHg}$ and diastolic more than $90 \mathrm{mmHg}$, first pregnancy (primigravida), maternal age less than 20 years or more than 35 years, and BMI before pregnancy> 25 or obesity. Women with a history of preeclampsia in previous pregnancies, chronic diseases and pregnancy complications such as twin fetuses, and antepartum bleeding (Bobak, L. \& Jensen, 2005). These various risk factors are often found with the poor healthy behavior of pregnant women.

Healthy living behaviors include nutritional status, hygiene, sanitation, awareness of healthy living and the reach and quality of health services around pregnant women. Economic status, education, ignorance, socio-cultural traditions, and geographical location are also sometimes become factors that can reduce the awareness of pregnant women about the risks, signs and symptoms of preeclampsia (Roeshadi, 2007). Therefore, to reduce the risk of preeclampsia in pregnant women action is needed including early prevention and management. One of the early preventions of the preeclampsia occurrence is by having good healthy living behavior. Healthy living behavior is applied to normal pregnant women as the prevention of preeclampsia. However, in West Java, there has been no research on healthy living behavior in pregnant women at risk of preeclampsia, even though the rate of preeclampsia itself is quite high in West Java. This study 
aimed to identify healthy behavior in pregnant women with a risk of preeclampsia in the work area of Ciparay Health Center, Bandung Regency.

\section{METHODS}

This research was a quantitative descriptive study to identify healthy life behaviors of pregnant women with a risk of preeclampsia. The population in this study were all pregnant women at risk of preeclampsia in the Ciparay District, Bandung, which was 36 people in Manggungharja Village. The sampling technique in this study used was total sampling. The study was conducted in August 2016 until January 2019.

The instrument used in this study was a questionnaire modified from the Health Promoting Lifestyle Profile II (Walker, Sechrist, \& Pender, 1995) adapted to the habits and conditions of Indonesian people such as number and portion of food, spiritual, and stress management. The modified instrument consists of 54 questions with 6 dimensions measured, namely health responsibility dimensions, physical activity dimensions, nutrition dimensions, spiritual growth dimensions, interpersonal relations dimensions, and stress management dimensions. The scale used was a Likert scale that provides 4 answer choices consisting of Never (1), Sometimes (2), Often (3), Always (4). This instrument has a validity test value between $0.494-0.864$ and the Cronbach alpha reliability test results is 0.950 .

\section{RESULTS}

Based on table 1 shows that most pregnant women (61.1\%) were 20-35 years old, primigravida $(41.7 \%)$, and trimester II pregnancy (47.2\%). Half of the pregnant women had a normal BMI (50.0\%). The last education of the respondent was mostly (63.9\%) elementary and junior high school. The majority of respondents were housewives $(86.1 \%$ ) and the average family income of respondents was less than Regional Minimum Wage or $\leq$ Rp. 2,700,000 (75.0\%). 
Table 1 Characteristics of Pregnant Women with Risk of Preeclampsia $(n=$ 36)

\begin{tabular}{|c|c|c|c|}
\hline \multicolumn{2}{|c|}{ Characteristics } & \multirow{2}{*}{$\begin{array}{c}\begin{array}{c}\text { Frequency } \\
\text { (f) }\end{array} \\
5\end{array}$} & \multirow{2}{*}{$\begin{array}{c}\begin{array}{c}\text { Percentage } \\
(\%)\end{array} \\
13.9\end{array}$} \\
\hline Age & $<20$ years old & & \\
\hline & 20 - 35 years old & 22 & 61.1 \\
\hline & $>35$ years old & 9 & 25.0 \\
\hline \multirow[t]{3}{*}{ Gravida } & 1 & 15 & 41.7 \\
\hline & $2-5$ & 20 & 55.6 \\
\hline & $>5$ & 1 & 2.80 \\
\hline \multirow[t]{3}{*}{ Gestational Age } & Trimester I & 4 & 11.1 \\
\hline & Trimester II & 17 & 47.2 \\
\hline & Trimester III & 15 & 41.7 \\
\hline \multirow[t]{4}{*}{ BMI before pregnancy } & Underweight $<18,5$ & 7 & 19.4 \\
\hline & Normal 18,5 - 24,9 & 18 & 50.0 \\
\hline & Overweight $25-29,9$ & 9 & 25.0 \\
\hline & Obesity $>30$ & 2 & 5.6 \\
\hline \multirow[t]{3}{*}{ Last education } & Elementary School & 23 & 63.9 \\
\hline & Middle School & 8 & 22.2 \\
\hline & College & 5 & 13.9 \\
\hline \multirow[t]{3}{*}{ Job } & Housewife & 31 & 86.1 \\
\hline & Laborer & 2 & 5.6 \\
\hline & Other & 3 & 8.3 \\
\hline \multirow[t]{2}{*}{ Income } & $\leq \mathrm{Rp} 2.700 .000$ & 27 & 75.0 \\
\hline & $>\operatorname{Rp} 2.700 .000$ & 9 & 25.0 \\
\hline
\end{tabular}

Table 2 Healthy Living Behavior in Pregnant Women with Preeclampsia Risk $(\mathbf{n}=36)$

\begin{tabular}{lccccc}
\hline Healthy Living Behavior in & \multicolumn{5}{c}{ Category } \\
\cline { 2 - 6 } $\begin{array}{c}\text { Pregnant Women with } \\
\text { Preeclampsia Risk }\end{array}$ & \multicolumn{3}{c}{ High } & \multicolumn{2}{c}{ Low } \\
\cline { 2 - 6 } & f & \% & f & \% \\
\hline Healthy living behavior & 20 & 55.56 & 16 & 44.44 \\
1. Health Responsibility & 22 & 61.11 & 14 & 38.89 \\
2. Physical Activity & 17 & 47.22 & 19 & 52.78 \\
3. Nutrition & 20 & 55.56 & 16 & 44.44
\end{tabular}




\begin{tabular}{llccc} 
4. Interpersonal Relations & 20 & 55.56 & 16 & 44.44 \\
5. Spiritual Growth & 28 & 77.78 & 8 & 22.22 \\
6. Stress Management & 18 & 50.0 & 18 & 50.0 \\
\hline
\end{tabular}

Based on table 2, it could be seen that more than half of pregnant women (55.56\%), as many as 20 respondents had healthy living behaviors in the high category. While in all dimensions shows the dimensions of spiritual growth, healthy living behavior of pregnant women was in the high category (77.78\%), and the dimensions of physical activity were in a low category $(52.78 \%)$.

Table 3 Items with the Lowest Score in Each Healthy Living Behavior Dimension

\begin{tabular}{cclc}
\hline No. & $\begin{array}{c}\text { Healthy Living } \\
\text { Behaviour Dimension }\end{array}$ & \multicolumn{1}{c}{ Question Items } & $\begin{array}{c}\text { Average } \\
\text { Score }\end{array}$ \\
\hline 1. & Health Responsibility & $\begin{array}{l}\text { I watched television programs } \\
\text { about a healthy lifestyle during } \\
\text { pregnancy }\end{array}$ & 2.31 \\
& &
\end{tabular}

2. Physical Activity

I did a variety of physical activities as recreation (eg swimming, pregnancy exercises)

3. Nutrition I avoided foods that contain high fat such as meatballs.

4. Interpersonal Relations If there was a problem, I discussed my problem with the people closest to me

5. Spiritual Growth I always prayed for the good of the people around me.

6. Stress Management I had a special method for dealing 2.22 with stress such as deep breathing

Based on table 3, the lowest average score was discovered which was the physical activity dimensions with an average score of (1.53), physical activity for example swimming, pregnancy exercise. This might be because there were still a few pregnant women who could swim in Ciparay. 


\section{DISCUSSION}

Based on the research, it was discovered that the majority of pregnant women had a high category of healthy living behavior and less than half of pregnant women were still in the low category. It means that the healthy living behavior of pregnant women with preeclampsia risk has been quite good and the rest is still poor.

This study finding in line with the research of Gokyildiz et al. (2014) in pregnant women in Turkey using the HPLP II instrument, it was discovered that the results of healthy living behavior in Turkey's pregnant women were at a moderate level or sufficient. The highest score was the spiritual growth dimensions and the lowest was the physical activity dimension. In contrast to Ratnawati's (2016) study of the healthy living behavior of pregnant women with preeclampsia in Pekalongan in 2015, it was found that $60.7 \%$ of respondents had unhealthy behavior. This was due to the limitations of pregnant women as housewives, in addition, socio-economic status also affects the healthy behavior of pregnant women. Pregnant women with preeclampsia tend to have poorer health behaviors than pregnant women who do not understand preeclampsia. So, it is very important for pregnant women with preeclampsia risk to maintain healthy living behavior.

In this study, different results were obtained in each item dimension of the need for healthy living. As in the high category of responsibility dimensions. The item questions with the highest average score was checking the pregnancy according to the recommendations of the health worker with a score of (3.69). The average pregnant woman with preeclampsia risk already had a good responsibility for her pregnancy, including regular pregnancy and blood pressure checks to prevent preeclampsia. While the question items that had the lowest average score was about the mothers watching television programs about healthy lifestyles during pregnancy with a score of (2.31). This is because there are very few shows on local television stations in Indonesia that provide information about a healthy lifestyle for pregnant women.

Healthy living behavior on the physical activity dimensions was a dimension that had a low average score. This means that pregnant women were 
still lacking in performing physical activities due to the limitations of mothers who were pregnant. In line with the research of Gokyildiz et al. (2014) in Turkey regarding healthy living behaviors in pregnant women, it was discovered that physical activity was the lowest dimension performed by pregnant women. Whereas pregnant women are recommended to do physical activities such as light exercise and weight management to avoid, therefore, reducing the risk of an increase in blood pressure. No one routinely does recreational physical activity. This is because most mothers were at the middle to lower economic level, so they rarely engaged in recreational physical activities such as swimming and pregnancy exercises. Ciparay area was still considered a rural area, there were still few swimming pools available and very few classes were held for pregnant women including pregnancy exercises. Physical activity was done in daily activities such as mopping, washing, sweeping and so on. Spracklen's research, Ryckman, Triche, \& Saftlas, (2016) discovered that women with higher levels of physical activity during pregnancy tended to have a lower risk of preeclampsia. Whereas women who have little or no physical activity during pregnancy tend to increase their risk of developing preeclampsia.

In the nutritional dimension, it was discovered that half of the respondents were in the high category. This means that there were many pregnant women with preeclampsia risk in Manggungharja Village who paid attention to nutritional intake during pregnancy. However, it is still lacking in the portion of food determined by the Indonesian Ministry of Health from each nutrient needed by the body. This could be seen from the average score of each question item with a score range of 1.89 to 3.67. The lowest item question in the nutritional dimension was about mothers avoiding high-fat foods. They never avoided fatty foods for reasons of habit and pleasure. In addition, pregnant women still did not limit consumption of sugar or foods that contained sugar. Consuming foods containing sugar will increase the risk of developing gestational diabetes. Some mothers had not limited the consumption of foods that contained high salt and caffeinated drinks, these foods had an impact on increasing blood pressure and an increase in the mother's heart rate, so the risk of developing preeclampsia increased. 
On the interpersonal relationships dimension, the results of pregnant women with preeclampsia risk already had high interpersonal relationships. The highest score question item was that the mother gets enough support from the family and care about her condition. In the dimensions of interpersonal relationships, it could be seen how the relationship between pregnant women and the people around them. Starting from mutual closeness, support each other, and the interpersonal relationships quality especially with husbands and families who are the closest people to mother. Good interpersonal relationships for pregnant women are very important. Changes in the physical, role and psychological conditions that occur in pregnant women, make a woman need more support from people around her to be able to undergo a good pregnancy.

In the stress management dimension, the results of respondents who had high and low levels of healthy behavior were 18 respondents $(50 \%)$. The average score of the stress management dimension was (3.16). This means that some respondents had good stress management. Good stress management in pregnant women with a high risk of preeclampsia is important because stress management affects three factors which are physical, psychological and social relations. Pregnant women with higher risk condition, previously suffered diseases or the condition of the fetus such as preeclampsia would cause pregnancy complications and disrupted the healthy behavior of the mother and cause stress to the mother. Interpersonal relationships also have a great influence on stress and stress management of pregnant women which are the basis of how mothers cope with stress well (Malakouti, Sehhati, Mirghafourvand, \& Nahangi, 2015).

The spiritual growth dimension had the highest average score found in this study. Almost all pregnant women had a high level of spiritual growth. A person's spiritual growth is very influential on the healthy living behavior of pregnant women with preeclampsia risk. This is directly related to the stress level and stress coping of the mother. For respondents who were Muslim, belief in prayer, recite the Qur'an, pray and have a relationship with God to calm the heart and reduce stress. Same goes with pregnant women with the risk of preeclampsia, a good spirit will lead to a sense of calm in the mother, so they could do cope with stress well, and the risk of preeclampsia decreases. 
Based on this research, most of the pregnant women with the risk of preeclampsia have good healthy living behavior. But the incidence of preeclampsia is still high in the Ciparay region. This, perhaps because of other factors that influence pregnant women with the risk of preeclampsia such as heredity from parents who had preeclampsia before. Community nurses and other health workers such as midwives and doctors who are in the health care field at the PHCpuskesmas are expected to work together to provide health education to pregnant women as a whole, especially those who have detected a risk of preeclampsia regarding healthy living behavior. The limitations of this study are on the modification of the instruments used, which may still be lacking in the context of Indonesia, so it is necessary to apply this instrument to other studies relating to healthy living behavior so that the content of the instrument is updated and upgraded continuously.

\section{CONCLUSION}

Based on the results of the study it was concluded that the healthy behavior of pregnant women at risk of preeclampsia was mostly in the high category. In each mention, the results of different levels of healthy living behavior are obtained, with a sequence of dimensions from high to low health behavior are spiritual growth, health responsibility, stress management, interpersonal relationships, physical activity, and nutrition.

\section{REFERENCES}

Bobak, L.\& Jensen. (2005). Buku Ajar Keperawatan Maternitas. Jakarta: EGC.

Cunningham, G., Leveno, K. J., Bloom, S. L., Hauth, J. C., Rouse, D. J., \& Spong, C. Y. (2010). Obstetrics Williams Volume 2 Edisi 23. Jakarta: Buku Kedokteran EGC.

Dinas Kesehatan Kab. Bandung. (2016). Laporan Tahunan 2015. Kabupaten Bandung: Dinas Kesehatan Kab. Bandung.

Dinas Kesehatan Provinsi Jawa Barat. (2016). Profil Kesehatan Provinsi Jawa Barat Tahun 2015. Bandung: Dinas Kesehatan Provinsi Jawa Barat. 
Gokyildiz, S., Alan, S., Elmas, E., Bostanci, A., \& Kucuk, E. (2014). Health Promoting Lifestyle Behaviours in Pregnant Women in Turkey. International Journal of Nursing Practice, 20 : 390-397.

Kemenkes RI. (2013). Data Dasar Puskesmas. Jakarta: Kementrian Kesehatan Republik Indonesia .

Kemenkes RI. (2014). Profil Kesehatan Indonesia 2014. Jakarta: Kementrian Kesehatan RI.

Kemenkes RI. (2015). Dokumen Hasil Tujuan Pembangunan Berkelanjutan. Jakarta: International NGO Forum on Indonesian Develompment.

Kemenkes RI. (2015). Profil Kesehatan Indonesia Tahun 2015. Jakarta: Kementrian Kesehatan RI.

Kemenkes RI. (2016). Buku Kesehatan Ibu dan Anak. Jakarta: Kemenkes RI dan JICA.

Kozier, B., Erb, G., Berman, A., \& Snyder, S. J. (2010). Buku Ajar Fundamental Keperawatan Konsep, Proses \& Praktik. Edisi 7 Vol 1. Jakarta: Penerbit Buku Kedokteran EGC.

Lin, Y.-H., Tsai, E.-M., Chan, T.-F., Chou, F.-H., \& Lin, Y.-L. (2009). Health Promoting Lifestyles and Related Factors in Pregnant Women. Chang Gung Medical Journal, 32 (6) : 650-661.

Malakouti, J., Sehhati, F., Mirghafourvand, M., \& Nahangi, R. (2015). Relationship between Health Promoting Lifestyle and Perceived Stress in Pregnant Women with Preeclampsia. Journal of Caring Sciences, 4 (2) : 155-163.

Notoatmodjo, S. (2012). Promosi Kesehatan dan Perilaku Kesehatan. Jakarta: Rineka Cipta.

Pender, N. J., Murdaugh, C. L., \& Parsons, M. A. (2015). Health Promotion in Nursing Practice Seventh Edition. New Jersey, USA: Pearson Education Inc.

Ratnawati. (2016). Perilaku Hidup Sehat pada Perempuan hamil Preeklampsia. The 4th University Research Coloqium 2016, 499-503. 
Roeshadi, R. (2007). Upaya Menurunkan Angka Kesakitan dan Angka Kematian Ibu pada Penderita Preeklampsia dan Eklampsia. Majalah Obstetri Ginekologi Indonesia Vol 31 No 3, 31 (3) : 123-133.

Saifuddin, A. B., Adriaansz, G., Wiknjosastro, G. H., \& Waspodo, D. (2006). Buku Acuan Nasional Pelayanan Kesejatan Maternal dan Neonatal. Jakarta: Yayasan Bina Pustaka Sarwono Prawirohardjo.

Spracklen, C. N., Ryckman, K. K., Triche, E. W., \& Saftlas, A. F. (2016). Physical Activity During Pregnancy and Subsequent Risk of Preeclampsia and Gestational Hypertension : a Case Control Study. Matern Child Health Journal, 20 (6) : 1193-1202.

Walker, S. N., Sechrist, K. R., \& Pender, N. J. (1987). The Health-Promoting Lifestyle Profile : Development and Psychometric Characteristics. Nursing Research, 36 (2) : 76-81.

Walker, S. N., Sechrist, K. R., \& Pender, N. J. (1995). Health Promotion Model Instruments to Measure Health Promoting Lifestyle : Health-Promoting Lifestyle Profile [HPLP II] (Adult Version). Deep Blue University of Michigan.

Wiknjosastro, H., Saifuddin, A. B., \& Rachimhadhi, T. (1999). Ilmu Kebidanan. Jakarta: Yayasan Bina Pustaka Sarwono Prawirohardjo. 